\title{
Decreased Cyp2E1 mRNA expression in human leucocytes in patients with fibrotic and inflammatory lung diseases
}

\author{
SIMONE HELMIG, JULIANE DÖHREL and JOACHIM SCHNEIDER \\ Institut und Poliklinik für Arbeits- und Sozialmedizin, Justus-Liebig-Universität, D-35392 Giessen, Germany
}

Received February 22, 2010; Accepted April 21, 2010

DOI: $10.3892 /$ ijmm_00000446

\begin{abstract}
Cytochrome P450 2E1 (CYP2E1), a phase I enzyme, is involved in the activation of a broad spectrum of procarcinogens. The importance of this enzyme for pharmacology is derived from its unique substrate spectrum. Large interindividual differences in the toxicity of its substrates are known. We investigated the quantitative Cyp2E1 mRNA expression in a cohort of patients with fibrotic and inflammatory lung diseases $(n=137)$ and healthy controls $(n=221)$ considering tobacco-smoke, exposure to asbestos, silica, organic dust or chemical irritating particles in relation to the C1053T (RsaI) polymorphism of Cyp2E1. For quantitative comparison of Cyp2E1 mRNA levels real-time PCR was performed using a LightCycler ${ }^{\circledR}$ System. Calculations of expression were made with the $2^{-\triangle \Delta C T}$ method. Detection of the C1053T (RsaI) polymorphism of the Cyp2E1 gene was performed by rapid capillary PCR with melting curve analysis. Fibrotic $(0.016 \pm 0.002 ; \mathrm{n}=52 ; \mathrm{p}=0.000)$ and inflammatory $(0.013 \pm 0.002$; $\mathrm{n}=16, \mathrm{p}=0.000$ ) lung disease patients showed a significantly reduced Cyp2E1 mRNA expression compared to healthy controls $(0.026 \pm 0.002 ; \mathrm{n}=206)$. Exposure to asbestos $(0.019 \pm 0.003 ; \mathrm{n}=40 ; \mathrm{p}=0.016)$, organic dust $(0.016 \pm 0.003$; $\mathrm{n}=39 ; \mathrm{p}=0.000)$ and irritative chemicals $(0.016 \pm 0.002 ; \mathrm{n}=22$; $\mathrm{p}=0.000)$ revealed a highly significant reduced Cyp2E1 expression. Cyp2E1 mRNA expression of occupational disease (OD) patients suffering from lung or pleural asbestosis ODNo. $4103(0.018 \pm 0,003 ; n=31 ; p=0.024)$, allergic obstructive airway diseases OD-No. $4301(0.013 \pm 0.002 ; n=23 ; \mathrm{p}=0.000)$, exogenic allergic alveolitis OD-No. $4201(0.009 \pm 0.002 ; n=6$; $\mathrm{p}=0.000$ ) and obstructive airway diseases caused by irritative
\end{abstract}

Correspondence to: Dr Simone Helmig, Institut und Poliklinik für Arbeits- und Sozialmedizin, der Justus-Liebig Universität, Aulweg 129, D-35392 Giessen, Germany

E-mail: simone.helmig@arbmed.med.uni-giessen.de

Abbreviations: LD, lung disease; OD, occupational disease; Cyp2E1, cytochrome P450 2E1; BKV, occupational diseases legacy; WBC, white blood cells; PY, pack-year; BMI, body-mass-index

Key words: cytochrome P450 2E1, fibrotic lung disease, inflammatory lung disease, gene expression, gene polymorphism, dust exposure chemicals OD-No. $4302(0.013 \pm 0.001 ; \mathrm{n}=11 ; \mathrm{p}=0.000)$ was highly significantly reduced. In conclusion, we demonstrated a significantly decreased mRNA expression in patients with fibrotic and inflammatory lung diseases compared to healthy controls.

\section{Introduction}

Increased anthropogenic pollution of the environment leads to a steady growth in cancer incidence world-wide. Long-term intake of carcinogenic compounds e.g. contained in tobacco smoke or occupational dust contributes to development of malignancies (1). The cytochrome P450 mono-oxygenase system (CYP) plays a major role in the metabolic initiation of xenobiotics into carcinogenic metabolites (2).

Cytochrome P450 2E1 (CYP2E1) plays an important role in biotransformation of procarcinogens. The importance of this enzyme in occupational and environmental medicine is derived from its unique substrate spectrum, that includes a number of high production chemicals, such as hydrocarbons, solvent and industrial monomers (3). Cyp2E1 also participates in metabolism of many compounds, including N-nitrosamines, benzene, acetaldehyde and phenol, which are amongst other ingredients of tobacco smoke (4). Its ability to reduce molecular oxygen to highly reactive compounds, even in the absence of substrates, leads to intensified damage of macromolecules and formation of DNA-adducts (1). The highest expression levels of Cyp2E1 are found in the liver (5) but it is also expressed in nasal and oropharyngeal epithelium (6), bronchial epithelium (7) and peripheral blood lymphocytes (8).

Molecular epidemiology can have an important impact when analyzing the complexity of gene-environment interactions at the molecular level. While gene mutations of high penetration often result in a high risk for cancer (9), polymorphisms of genes with low penetration (such as Cyp2E1), are thought to predispose the individual risk if there is exposure to a certain chemical (10).

Since the Cyp2E1 gene is polymorphic and significant individual variability was found for its gene expression level (11), it can be assumed that polymorphisms, at least partially, explain the inherited individual susceptibility to development of malignancies (1).

A single nucleotide polymorphism $(\mathrm{C} / \mathrm{T})$ was identified in 5'-regulatory region of Cyp2E1 at position -1053, which is accompanied with the loss of a RsaI restriction site (accession no. gene J02843). Gene analyses indicate that the rare c2 allele is accompanied with a higher expression $(12,13)$. 
Table I. Demographic parameters of healthy controls (HC) and lung disease patients (LD).

\begin{tabular}{|c|c|c|c|}
\hline & Overall & $\begin{array}{l}\text { Healthy } \\
\text { controls }\end{array}$ & $\begin{array}{c}\text { Occupational } \\
\text { disease }\end{array}$ \\
\hline $\mathrm{N}$ & 358 & 221 & 137 \\
\hline \multicolumn{4}{|l|}{ Age } \\
\hline Mean & 37 & 27 & 62 \\
\hline Min & 15 & 15 & 18 \\
\hline Max & 85 & 77 & 85 \\
\hline \multicolumn{4}{|l|}{ Gender } \\
\hline Male & 216 & 99 & 117 \\
\hline Female & 142 & 122 & 20 \\
\hline \multicolumn{4}{|l|}{ Cyp2E1 genotype } \\
\hline wt/wt & 335 & 210 & 125 \\
\hline $\mathrm{wt} / \mathrm{mt}$ & 22 & 11 & 11 \\
\hline $\mathrm{mt} / \mathrm{mt}$ & 1 & 0 & 1 \\
\hline Frequency q(mt) & 0.0335 & 0.0249 & 0.052 \\
\hline \multicolumn{4}{|l|}{ Smoking habbit } \\
\hline Smoker & 112 & 88 & 24 \\
\hline Non-smoker & 178 & 122 & 56 \\
\hline Ex-smoker & 68 & 11 & 57 \\
\hline
\end{tabular}

To demonstrate the functional impact of occupational or environmental factors we investigated the quantitative Cyp2E1 mRNA expression in a cohort of people with fibrotic and inflammatory lung disease $(n=137)$ as well as in a cohort of healthy controls $(n=221)$ tobacco use, exposure to asbestos, silica, organic dust or irritating chemical particles in relation to the C1053T (RsaI) polymorphism of Cyp2E1.

\section{Materials and methods}

Subjects. The study population consisted of a total of 358 Caucasians (mean age 37 years; range, 15-85 years). Volunteers were personnel of the Universitätsklinikum Giessen und Marburg GmbH, students of the Justus-Liebig-Universität Giessen as well as patients recruited at the Policlinic of the Institute for Arbeits- and Sozialmedizin Giessen, Germany.

All subjects included in this study were interviewed using a questionnaire to obtain information on lifestyle including smoking habits, alcohol consumption, indoor air pollution (coal heating and cooking), eating habits and lifetime occupational and disease history. The control group composed of 221 unrelated healthy subjects (mean age 27 years; range, 15-77 years) without known diseases. Any subject with diseases related to potential lung disorders (chronic obstructive lung disease, etc.) or any benign or malignant tumours were excluded Table I).

The fibrotic and inflammatory lung diseases (LD) group composed 137 people (mean age 62 years; range, 18-85 years). Occupational diseases consisted LD 1, 54 people with lung fibrosis including asbestosis, silicosis and idiopathic pulmonary disease; LD 2, 67 people with obstructive airway diseases including chronic obstructive lung disease (COLD), unspecific bronchial hyperreactivity (UBH) and asthma; LD 3, 16 people
Table II. Exposure at the workplace and compensated occupational disease according to the numbers as defined in the list of occupational diseases (BKV).

\begin{tabular}{lccr}
\hline Exposure to & N & BKV No. & N \\
\hline Asbestos & 42 & 4103 & 32 \\
Silica & 13 & 4101 & 8 \\
Organic dust & 41 & 4301 & 24 \\
& & 4201 & 6 \\
Irritative chemical & 22 & 4302 & 11 \\
\hline
\end{tabular}

with other inflammatory lung diseases including sarcoidosis, tuberculosis, (broncho-) pneumonia, (tracheo-) bronchitis, floride exogenic allergic alveolitis (farmer lung disease) and pleural empyema. To allow further discrimination between different kinds of exposure, several subgroups with exposure to asbestos, silica, organic dust and irritative chemicals were created. In addition patients with recognized occupational diseases were compared by their occupational disease (OD) numbers (Table II).

Smokers $(n=112)$ were defined as people who smoke daily, non-smokers $(n=178)$ were defined as people who had never smoked and ex-smokers $(n=68)$ were defined as people who had quit smoking at least 3 months previously.

The ethics committee of the university hospital, Giessen, Germany, approved the study. All subjects gave written informed consent for the study.

Real-time PCR and polymorphism detection. Blood samples (ca. $3 \mathrm{ml}$ ) were obtained from all subjects. Genomic DNA was isolated from whole blood using the Versagene ${ }^{\mathrm{TM}}$ DNA Purification Kit (Gentra Systems, Minneapolis, USA) according to the manufactures instruction. Detection of the C1053T (RsaI) polymorphism of the Cyp2E1 gene was performed by rapid capillary PCR, with melting curve analysis, using fluorescence-labelled hybridisation probes in a LightCycler ${ }^{\circledR}$ System (14). The wild-type allele (C) containing the RsaI site is referred to as $\mathrm{cl}$ and the rare allele $(\mathrm{T})$ without the RsaI site is referred to as c2 (15). At the home page of the Human Cytochrome P450 (CYP) Allele Nomenclature Committee (www.cypalleles.ki.se/) the polymorphism was named Cyp2E1*5B, while the wild-type allele was designated as Cyp2E1*1A (16).

Both negative and positive controls were included in each PCR reaction. TIB Molbiol, Berlin, Germany, synthesized the PCR primers as well as the fluorescent-labelled detection probes. The primers Cyp2E1-sense (5'-AGAATGGCATAA CTCAAAATCC-3') and Cyp2E1-antisense (5'-CAGACCC TCTTCCACCTTCTAT-3') amplify a 364-bp fragment of the Cyp2E1 5' flanking region. The fluorescein-labeled probe (TTCATTGTTAATATAAAAGTACAAAATT-FL) and the LC-Red640-labeled probe (LC-Red640-CAACCTATGAAT TAAGAACTTCTATATATTGCCAG-PH) bind to nucleotides 1751-1778 and 1780-1814 within the human Cyp2E1 gene (GenBank entry J02843), respectively. The expected melting curve in the case of the wild-type $\mathrm{C}$ allele (c1) was higher than in the case of the rare $\mathrm{T}$ allele (c2). The homozygous samples for the $\mathrm{C}$ allele (Cyp2E1 c1/c1) contain a single peak and a 


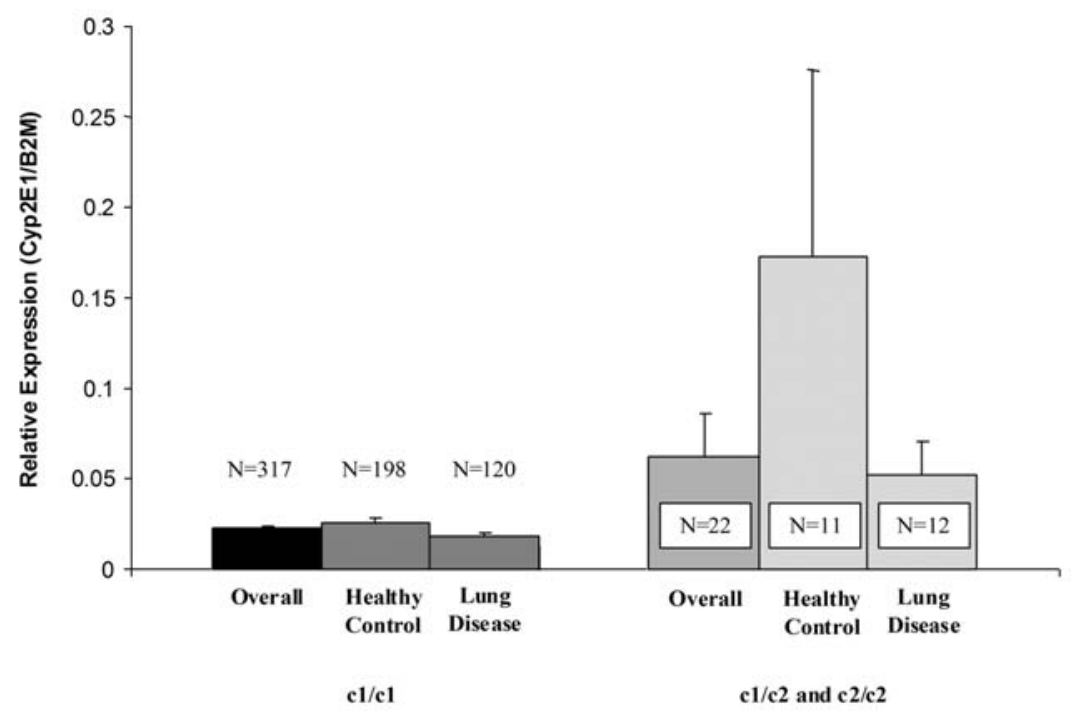

Figure 1. The quantitative Cyp2E1 mRNA expression among different genotypes for Cyp2E1 C-1053T polymorphism (c1/c1, c1/c2 and c2/c2) was analysed. All genotypes, carrying at least one $\mathrm{c} 2$ allele are combined in one group. Relative expression of Cyp2E1 to B2M is presented in the investigated population overall, in the healthy control group (HC) and the lung disease (LD) group. Data are shown as means $\pm \mathrm{SE},{ }^{*} \mathrm{p}<0.05$.

melting temperature of $55^{\circ} \mathrm{C}$, and homozygous samples for the $\mathrm{T}$ allele (Cyp2E1 c2/c2) show a single peak at $47.5^{\circ} \mathrm{C}$. Heterozygous (Cyp2E1 c1/c2) samples give rise to biphasic melting curves (Fig. 1). In the following homozygous genotype Cyp2E1 $\mathrm{c} 1 / \mathrm{c} 1$ is denoted ' $\mathrm{c} 1 / \mathrm{c} 1$ ', heterozygous genotype Cyp2E1 c1/c2 is denoted 'c1/c2' and homozygous genotype Cyp2E1 c2/c2 is denoted 'c $2 / \mathrm{c} 2$ '.

Reaction mixture (modified) (14) comprised 1x FastStart DNA Master Hybridization Probes (Roche Diagnostics, Mannheim, Germany), primers Cyp2E1-sense $(1.5 \mu \mathrm{M})$ and Cyp2E1-antisense $(1.5 \mu \mathrm{M})$, sensor $(0.25 \mu \mathrm{M})$, anchor $(0.25 \mu \mathrm{M}), \mathrm{MgCl}_{2}(4 \mathrm{mM}), 25 \mathrm{ng}$ of genomic DNA in a $10 \mu \mathrm{l}$ reaction mixture. PCR contamination was checked by the inclusion of a negative control. PCR was initially denatured at $95^{\circ} \mathrm{C}$ for $10 \mathrm{~min}$ and subjected to 50 cycles of amplification with $2 \mathrm{sec}$ of denaturing at $95^{\circ} \mathrm{C}, 10 \mathrm{sec}$ of annealing at $55^{\circ} \mathrm{C}$, and $20 \mathrm{sec}$ of extension at $72^{\circ} \mathrm{C}$. The melting curve was achieved by $2 \mathrm{sec}$ at $95^{\circ} \mathrm{C}, 30 \mathrm{sec}$ at $36^{\circ} \mathrm{C}$ and $1 \mathrm{sec}$ at $90^{\circ} \mathrm{C}$ $\left(0.1^{\circ} \mathrm{C} / \mathrm{sec}\right)$.

RNA extraction and reverse transcription. White blood cells (WBC) were isolated from $10 \mathrm{ml}$ peripheral blood using Ficoll ${ }^{\circledR}$ (GE Healthcare) as described by the manufacturer. Total RNA was isolated from WBCs using a commercial RNA isolation reagent (TRI Reagent ${ }^{\circledR}$, Sigma) according to the manufacturer's instructions. Isolated RNA was resuspended in $10 \mu \mathrm{l}$ of RNase-free water. Each sample was treated twice with $2 \mu \mathrm{l}$ RNase-free DNase $1 \mathrm{unit} / \mu \mathrm{l}$ (Qiagen) for $10 \mathrm{~min}$ at $37^{\circ} \mathrm{C}$ to eliminate remaining DNA. Prepared RNA was reverse-transcribed as described (17).

Real-time polymerase chain reaction (PCR). For quantitative comparison of Cyp2E1 mRNA levels real-time PCR was performed using SYBR-green fluorescence in a LightCycler ${ }^{\circledR}$ System (Roche Diagnostic GmbH). After optimization of PCR conditions, amplification efficiency was tested in standard curves using serial cDNA dilutions. The correlation coefficient had to be $>0.9$ and the slope about -3.5 . Amplification specificity was checked using melting curves. Both negative and positive controls were included in each PCR reaction. All assays were carried out three times as independent PCR runs for each cDNA sample. Gene expression was always related to the expression of $\beta-2$-microglobulin (B2M) as the housekeeping gene, which is known as a suitable choice for normalization of leucocyte expression levels (18). Calculations of expression were performed with the $2^{-\triangle \triangle C T}$ method according to Pfaffl (19). Gene expression levels were rounded to three decimal places. Sequences of the specific primers for CYP2E1 and B2M were CYP2E1-SP (5'CCT ACA TGG ATG CTG TGG TG-3'), CYP2E1-ASP (5'TGG GGA TGA GGT ATC CTC TG-3'), and B2M-for (5'-ACTGAATTCACCCCCACTGA-3'), B2Mrev (5'-CCTCCATGATGATGCTTACA-3'). PCR reactions were carried out in a final volume of $20 \mu \mathrm{l}$ using $1 \mathrm{x}$ Absolut ${ }^{\mathrm{TM}}$ QPCR SYBR Green Capillary Mixes (Abgene), $300 \mathrm{nM}$ of $\mathrm{B} 2 \mathrm{M}$ primers or $600 \mathrm{nM}$ of Cyp2E1 primers and $2 \mu \mathrm{l} \mathrm{cDNA}$. The PCR conditions for Cyp2E1 were as follows: initial denaturation $15 \mathrm{~min}$ at $95^{\circ} \mathrm{C}$, touch-down PCR 2 cycles of $95^{\circ} \mathrm{C}$ for $10 \mathrm{sec}, 65^{\circ} \mathrm{C}$ for $10 \mathrm{sec}, 72^{\circ} \mathrm{C}$ for $25 \mathrm{sec} ; 2$ cycles of $95^{\circ} \mathrm{C}$ for $10 \mathrm{sec}, 63^{\circ} \mathrm{C}$ for $10 \mathrm{sec}, 72^{\circ} \mathrm{C}$ for $25 \mathrm{sec} ; 2$ cycles of $95^{\circ} \mathrm{C}$ for $10 \mathrm{sec}, 61^{\circ} \mathrm{C}$ for $10 \mathrm{sec}, 72^{\circ} \mathrm{C}$ for $25 \mathrm{sec} ; 45 \mathrm{cycles}$ of $95^{\circ} \mathrm{C}$ for $10 \mathrm{sec}, 59^{\circ} \mathrm{C}$ for $10 \mathrm{sec}, 72^{\circ} \mathrm{C}$ for $25 \mathrm{sec}$. PCR conditions for $\mathrm{B} 2 \mathrm{M}$ were as follows, initial denaturation for $15 \mathrm{~min}$ at $95^{\circ} \mathrm{C}$, PCR 55 cycles of $95^{\circ} \mathrm{C}$ for $10 \mathrm{sec}, 63^{\circ} \mathrm{C}$ for $10 \mathrm{sec}, 72^{\circ} \mathrm{C}$ for $10 \mathrm{sec}$.

All measurements were made without information about the origin of the samples and were performed in triplicate. After amplification reaction products were controlled and separated on $2 \%$ agarose gels, stained with SYBR Safe, and photographed under UV illumination.

Statistical analysis. All statistical analyses were performed using the statistical software package, SSPS 15.0 (SPSS Inc., Chicago, IL, USA). Allelic and genotype frequencies were obtained by direct counting. Hardy-Weinberg equilibrium was assessed by the $\chi^{2}$ test with 1 degree of freedom. Results are expressed as mean \pm standard error of the mean (SE). 


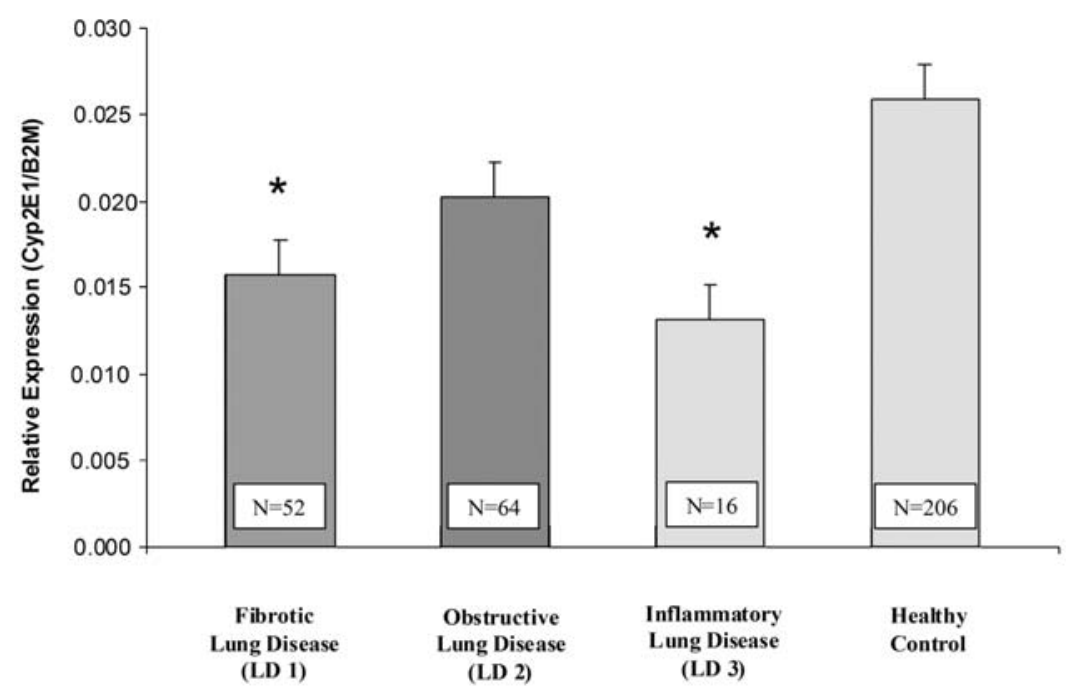

Figure 2. Quantitative mRNA expression of Cyp2E1/B2M in leucocytes was determined among different lung disease (LD) groups. Fibrotic lung diseases (LD 1) obstructive airway diseases (LD 2) and inflammatory lung diseases (LD 3) were compared to healthy controls. Data are shown as means \pm SE, * $\mathrm{p}<0.05$.

Means in different subgroups were analysed by Student's t-test and one-way ANOVA. A value of $\mathrm{p}<0.05$ was regarded as significant.

\section{Results}

Allele frequencies. To determine whether our studied population deviated from the Hardy-Weinberg equilibrium and if allele frequencies were within other published frequencies, we investigated allele and genotype frequencies in the total population as well as in the control and patient groups.

In the total population the allele frequency for $\mathrm{q}(\mathrm{Cyp} 2 \mathrm{E} 1 \mathrm{c} 2)$ was 0.034 . This allele frequency is similar to other observed frequencies in various healthy Caucasian populations and did not significantly deviate from the Hardy-Weinberg equilibrium. The allele frequencies within the healthy control group was $\mathrm{q}($ Cyp2E1 c2) $=0.025$ and within the patient group was $\mathrm{q}($ Cyp2E1 c2 $)=0.052$. Neither group deviated from the Hardy-Weinberg equilibrium.

Cyp2E1 allelic variants and Cyp2E1 mRNA expression. To investigate the functional impact of the Cyp2E1 allelic variants, the quantitative Cyp2E1 mRNA expression among different genotypes for Cyp2E1 C-1053T polymorphism (c1/c1, c1/c2, $\mathrm{c} 2 / \mathrm{c} 2$ ) was analysed. Since the allele frequency of the $\mathrm{c} 2$ allele is low within the Caucasian population, we combined all genotypes, carrying a c2 allele, in one group. Comparing the means $\pm \mathrm{SE}$ of the relative Cyp2E1 mRNA expression did not reveal any significant differences between the homozygote genotypes (c1/c1) and the $\mathrm{c} 2$ allele carrying genotypes $(\mathrm{c} 1 / \mathrm{c} 2, \mathrm{c} 2 / \mathrm{c} 2)$. The $\mathrm{c} 2$ allele carrying genotypes tends to result in higher mRNA expression for the total population $(0.023 \pm 0.001 ; n=317$ vs. $0.062 \pm 0.024 ; n=22)$, as well as for the healthy control $(0.026 \pm 0.002 ; n=198$ vs. $0.172 \pm 0.103$; $\mathrm{n}=11)$ and the patient group $(0.018 \pm 0.002 ; \mathrm{n}=120 \mathrm{vs}$. $0.052 \pm 0.019 ; \mathrm{n}=12)$. This suggests that genotypes carrying the c2 allele have a higher Cyp2E1 mRNA expression compared to the genotype without the $\mathrm{c} 2$ allele (Fig. 1).
Possible functional impacts on Cyp2E1 mRNA expression. We further investigated the functional impact of the smoking status, gender, body mass index (BMI) and age on the quantitative Cyp2E1 mRNA expression. Analysis in the total population as well as in the subgroups did not reveal any relevant differences in Cyp2E1 mRNA expression between smokers, non-smokers and ex-smokers or between males and females (data not shown). Relative Cyp2E1 mRNA expression in context with the BMI produced a coefficient of determination $\mathrm{R}^{2}=0.032$ overall, $\mathrm{R}^{2}=0.00001$ healthy subgroup and $\mathrm{R}^{2}=0.02$ patient group. Relative Cyp2E1 mRNA expression in context of age produced a coefficient of determination $\mathrm{R}^{2}=0.011$ overall, $\mathrm{R}^{2}=0.003$ healthy subgroup and $R^{2}=0.012$ patient group. Therefore we conclude that the smoking habits, gender, BMI and age do not influence Cyp2E1 mRNA expression.

Ethiology and Cyp2E1 mRNA expression. The lung diseases (LD) group was further divided in fibrotic lung diseases (LD 1) including asbestosis, silicosis and idiopathic pulmonary disease, in obstructive lung diseases (LD 2) including chronic obstructive lung disease (COLD), unspecific bronchial hyperreactivity (UBH) and asthma as well as in inflammatory lung diseases (LD 3), including sarcoidosis, tuberculosis, (broncho-) pneumonia, (tracheo-) bronchitis, floride exogenic allergic alveolitis (farmer lung disease) and pleural empyma. The two subgroups, LD $1(0.016 \pm 0.002 ; n=52 ; \mathrm{p}=0.000)$ and LD $3(0.013 \pm 0.002 ; \mathrm{n}=16 ; \mathrm{p}=0.000)$, showed significantly reduced Cyp2E1 mRNA expression compared to the healthy control group $(0.026 \pm 0.002 ; n=206)$. This was also seen in the subgroup LD $2(0.020 \pm 0.002 ; n=64 ; \mathrm{p}=0.053)$ however, a significance was not reached (Fig. 2).

Exposure and Cyp2E1 mRNA expression. For further investigations subgroups with exposure to asbestos, silica, organic dust and irritative chemicals were formed. Cyp2E1 mRNA expression of these subgroups was compared to healthy controls without any known exposure at the workplace. 


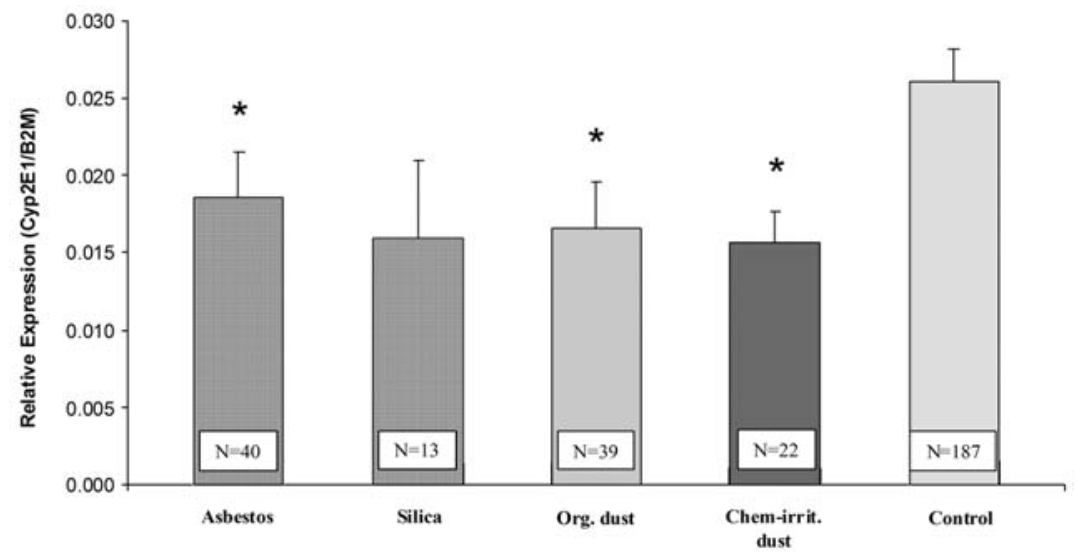

Figure 3. Quantitative mRNA expression of Cyp2E1/B2M was determined among the different exposure groups: asbestos, silica, organic dust and irritative chemicals. Cyp2E1 mRNA expression of these subgroups was compared to unexposed healthy controls without any known exposure at the workplace. Data are shown as means $\pm \mathrm{SE},{ }^{*} \mathrm{p}<0.05$.

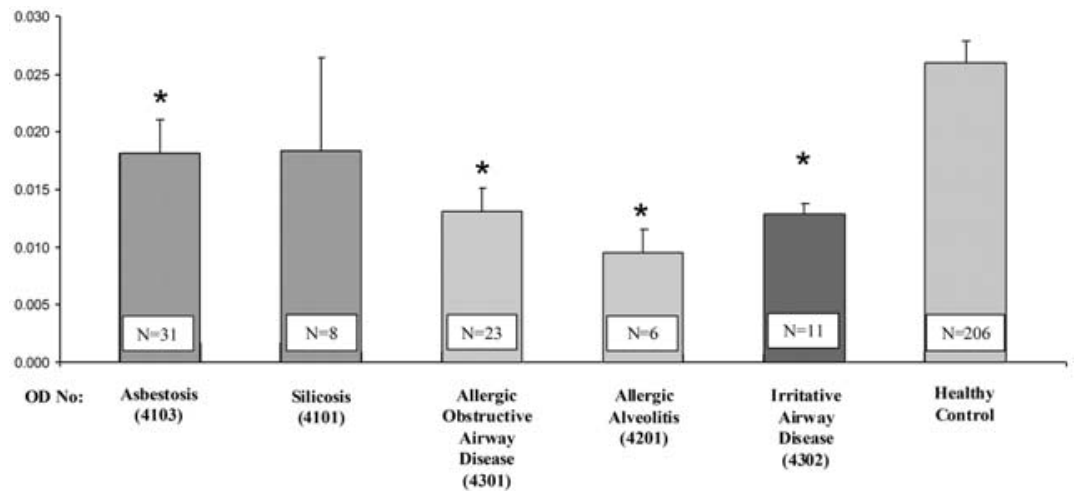

Figure 4. The quantitative Cyp2E1 mRNA expression among patients with recognized occupational diseases were compared by their type of occupational disease (OD). Verified occupational diseases are as followed: No. 4103 (BKV) patients with lung or pleural asbestosis; No. 4101 silicosis; No. 4301 allergic obstructive airway diseases; No. 4201 exogenic allergic alveolitis; No. 4302 obstructive airway diseases caused by irritative chemicals at the workplace. Data are shown as means $\pm \mathrm{SE},{ }^{*} \mathrm{p}<0.05$.

The asbestos exposure group $(0.019 \pm 0.003 ; \mathrm{n}=40 ; \mathrm{p}=0.016)$ but not the silica exposure group $(0.016 \pm 0.005 ; n=13$; $\mathrm{p}=0.095)$ showed a significantly reduced Cyp2E1 mRNA expression compared to the healthy controls $(0.026 \pm 0.002$; $\mathrm{n}=197)$. Additionally, exposure to organic dust $(0.016 \pm 0.003$; $\mathrm{n}=39 ; \mathrm{p}=0.000)$ and irritative chemicals $(0.016 \pm 0.002 ; \mathrm{n}=22$; $\mathrm{p}=0.000$ ) revealed a highly significant reduced Cyp2E1 mRNA expression (Fig. 3).

Occupational diseases and Cyp2E1 mRNA expression. In addition patients with recognized occupational diseases were compared by their occupational disease (OD) according the numbers as defined in the list of occupational diseases legacy (BKV). The verified occupational diseases are as follows: No. 4103 (BKV) patients with lung or pleural asbestosis; No. 4101 silicosis; No. 4301 allergic obstructive airway diseases; No. 4201 exogenic allergic alveolitis; No. 4302 obstructive airway diseases caused by irritative chemicals at the workplace. Cyp2E1 mRNA expression of No. 4103 $(0.018 \pm 0.003 ; n=31 ; p=0.024)$, but not No. $4101(0.018 \pm 0.008$; $\mathrm{n}=8 ; \mathrm{p}=0.410)$ was significantly reduced compared to healthy controls $(0.026 \pm 0.002 ; n=206)$. Additionally, No. 4301 $(0.013 \pm 0.002 ; \mathrm{n}=23 ; \mathrm{p}=0.000)$, No. $4201(0.009 \pm 0.002 ; \mathrm{n}=6$; $\mathrm{p}=0.000)$ and No. $4302(0.013 \pm 0.001 ; \mathrm{n}=11 ; \mathrm{p}=0.000)$ revealed a highly significant reduced Cyp2E1 mRNA expression (Fig. 4).

\section{Discussion}

In our study we demonstrated a higher mRNA expression for genotypes carrying at least one of the rare c2 allele. Since the allele frequency (c2) was low at 0.034 we determined only $22 \mathrm{c} 2$ allele carriers. Therefore, significance was not reached. Still our result is affirmed by gene analyses, which indicate that the rare c2 allele is accompanied with a higher mRNA expression $(12,13)$. Increased mRNA expression does not necessarily reflect enzyme activity level, but still evidence was obtained on increased catalytic activity of the enzyme coded by the c2 allele $(13,20)$. Cyp2E1 is involved in the metabolism of many procarcinogens and possesses the ability to reduce molecular oxygen to highly reactive compounds, leading to intensified lipid and protein peroxidation, DNA damage and carcinogenesis (21). Therefore a higher cancer risk would be expected to associate with the $\mathrm{c} 2$ allele.

Instead an increased risk for the development of esophageal cancer in the Chinese population, associated with the $\mathrm{c} 1 / \mathrm{c} 1$ 
genotype has been reported $(22,23)$. An association between the $\mathrm{c} 1 / \mathrm{c} 1$ genotype and an increased lung cancer risk was reported as well $(24,25)$. Among Asians the c2 allele of Cyp2E1 is suggested to be a decreased risk factor for developing lung cancer (26). Striking inter-ethnic differences, complicating analysis, appear with respect to the rare $\mathrm{c} 2$ alleles frequency.

The rare allele frequencies reported are $24-30 \%$ for Asians $(15,27,28), 2-3 \%$ for Caucasians $(20,27), 0.3-7 \%$ for Afro-Americans $(27,29,30), 15 \%$ for Mexican-Americans (29) and $18 \%$ for Taiwanese (31).

We demonstrated in our study a significant reduced Cyp2E1 mRNA expression of patients with fibrotic (LD 1) and inflammatory lung diseases (LD 3) compared to a healthy control group. In patients with an exposure to asbestos, organic dust and irritative chemicals Cyp2E1 mRNA expression was significantly reduced. These results were confirmed in patients with compensated occupational disease (OD). Smoking status, gender, body mass index (BMI) or age did not influence the quantitative Cyp2E1 mRNA expression in our study.

Transcription of the Cyp2E1 gene is primarily due to the binding of the hepatocyte-specific transcription factor HNF-1 upstream of the start site for RNA synthesis (32). The enzyme Cyp2E1 is regulated by transcriptional activation, mRNA stabilization, increased mRNA translatability and decreased protein degradation (33).

Inflammatory cytokines such as interleukin-6, $-1 \beta$ and tumor necrosis factor $\alpha(\mathrm{TNF}-\alpha)$ are reported to inhibit Cyp2E1 expression in rat hepatoma cells (34). Additionally a remarkable decrease of Cyp2E1 mRNA according to the fibrosis stage progression of chronic hepatitis $\mathrm{C}$ patients with liver fibrosis was also reported. This decrease was associated with an elevated production of proinflammatory cytokines, including TNF- $\alpha$ (35). The Cyp2E1 promoter activity also was demonstrated to be negatively regulated by oxidative stress in HepG2-cells (36). In contrast, interleukin-4, an antiinflammatory cytokine, induces the expression of the Cyp2E1 enzyme (37).

The above suggests that the decrease of Cyp2E1 mRNA is through the inflammation degree and the amount of inflammatory cytokines. The exact molecular mechanisms leading to a modification of Cyp2E1 transcription remain to be elucidated. This will be of great importance for understanding the basis for pharmacological and toxicological actions of a number of xenobiotic chemicals. Further studies will be needed to detect inflammatory cytokine levels and to determine the effect of the decreased mRNA levels on its protein. Additionally, it needs to be determined if results gained from leucocytes account as a marker for processes of organs such as the lung.

In conclusion, we demonstrated significantly decreased mRNA expression in patients with fibrotic and inflammatory lung diseases compared to healthy controls.

\section{References}

1. Danko IM and Chaschin NA: Association of CYP2E1 gene polymorphism with predisposition to cancer development. Exp Oncol 27: 248-256, 2005.

2. Bartsch H, Nair U, Risch A, Rojas M, Wikman H and Alexandrov K: Genetic polymorphism of CYP genes, alone or in combination, as a risk modifier of tobacco-related cancers. Cancer Epidemiol Biomarkers Prev 9: 3-28, 2000.
3. Bolt HM, Roos PH and Thier R: The cytochrome P-450 isoenzyme CYP2E1 in the biological processing of industrial chemicals: consequences for occupational and environmental medicine. Int Arch Occup Environ Health 76: 174-185, 2003.

4. Cederbaum AI: CYP2E1 - biochemical and toxicological aspects and role in alcohol-induced liver injury. Mt Sinai J Med 73: 657-672, 2006.

5. Shimada T, Yamazaki H, Mimura M, Inui Y and Guengerich FP: Interindividual variations in human liver cytochrome P-450 enzymes involved in the oxidation of drugs, carcinogens and toxic chemicals: studies with liver microsomes of 30 Japanese and 30 Caucasians. J Pharmacol Exp Ther 270: 414-423, 1994.

6. Lieber CS: The discovery of the microsomal ethanol oxidizing system and its physiologic and pathologic role. Drug Metab Rev 36: 511-529, 2004

7. Crawford EL, Weaver DA, DeMuth JP, et al: Measurement of cytochrome P450 2A6 and 2E1 gene expression in primary human bronchial epithelial cells. Carcinogenesis 19: 1867-1871, 1998.

8. Wang AH, Zhu SM, Qiu YL, et al: CYP2E1 mRNA expression, genetic polymorphisms in peripheral blood lymphocytes and liver abnormalities in Chinese VCM-exposed workers. Int J Occup Med Environ Health 21: 141-146, 2008.

9. Caporaso $\mathrm{N}$ and Goldstein A: Cancer genes: single and susceptibility: exposing the difference. Pharmacogenetics 5: 59-63, 1995.

10. Wunsch Filho V and Zago MA: Modern cancer epidemiological research: genetic polymorphisms and environment. Rev Saude Publica 39: 490-497, 2005.

11. Powell H, Kitteringham NR, Pirmohamed M, Smith DA and Park BK: Expression of cytochrome P4502E1 in human liver: assessment by mRNA, genotype and phenotype. Pharmacogenetics 8: 411-421, 1998 .

12. Hayashi S, Watanabe J and Kawajiri K: Genetic polymorphisms in the 5'-flanking region change transcriptional regulation of the human cytochrome P450IIE1 gene. J Biochem 110: 559-565, 1991.

13. Watanabe J, Hayashi S and Kawajiri K: Different regulation and expression of the human CYP2E1 gene due to the RsaI polymorphism in the 5'-flanking region. J Biochem 116: 321-326, 1994.

14. Choi JY, Abel J, Neuhaus T, et al: Role of alcohol and genetic polymorphisms of CYP2E1 and ALDH2 in breast cancer development. Pharmacogenetics 13: 67-72, 2003.

15. Watanabe J, Hayashi S, Nakachi K, et al: PstI and RsaI RFLPs in complete linkage disequilibrium at the CYP2E gene. Nucleic Acids Res 18: 7194, 1990.

16. Umeno M, McBride OW, Yang CS, Gelboin HV and Gonzalez FJ: Human ethanol-inducible P450IIE1: complete gene sequence, promoter characterization, chromosome mapping, and cDNAdirected expression. Biochemistry 27: 9006-9013, 1988.

17. Helmig S, Hadzaad B, Dohrel J and Schneider J: Influence of the Cyp1B1 L432V gene polymorphism and exposure to tobacco smoke on Cyp1B1 mRNA expression in human leukocytes. Drug Metab Dispos 37: 1490-1495, 2009.

18. Vandesompele J, De Preter K, Pattyn F, et al: Accurate normalization of real-time quantitative RT-PCR data by geometric averaging of multiple internal control genes. Genome Biol 3: Research0034, 2002

19. Pfaffl MW: A new mathematical model for relative quantification in real-time RT-PCR. Nucleic Acids Res 29: e45, 2001.

20. Carriere V, Berthou F, Baird S, Belloc C, Beaune P and de Waziers I: Human cytochrome P450 2E1 (CYP2E1): from genotype to phenotype. Pharmacogenetics 6: 203-211, 1996.

21. Ingelman-Sundberg M, Johansson I, Yin H, et al: Ethanolinducible cytochrome P4502E1: genetic polymorphism, regulation, and possible role in the etiology of alcohol-induced liver disease. Alcohol 10: 447-452, 1993.

22. Lu XM, Zhang YM, Lin RY, et al: Relationship between genetic polymorphisms of metabolizing enzymes CYP2E1, GSTM1 and Kazakh's esophageal squamous cell cancer in Xinjiang, China. World J Gastroenterol 11: 3651-3654, 2005.

23. Lin DX, Tang YM, Peng Q, Lu SX, Ambrosone CB and Kadlubar FF: Susceptibility to esophageal cancer and genetic polymorphisms in glutathione S-transferases T1, P1, and M1 and cytochrome P450 2E1. Cancer Epidemiol Biomarkers Prev 7: 1013-1018, 1998.

24. Li Z, Tan W and Shao K: [Susceptibility to lung cancer in Chinese is associated with genetic polymorphism in cytochrome P4502E1]. Zhonghua Zhong Liu Za Zhi 22: 5-7, 2000. 
25. Persson I, Johansson I, Lou YC, et al: Genetic polymorphism of xenobiotic metabolizing enzymes among Chinese lung cancer patients. Int J Cancer 81: 325-329, 1999.

26. Zhan P, Wang J, Zhang Y, et al: CYP2E1 Rsa I/Pst I polymorphism is associated with lung cancer risk among Asians. Lung Cancer (In press)

27. Kato S, Shields PG, Caporaso NE, et al: Cytochrome P450IIE1 genetic polymorphisms, racial variation, and lung cancer risk. Cancer Res 52: 6712-6715, 1992.

28. Tan W, Song N, Wang GQ, et al: Impact of genetic polymorphisms in cytochrome P450 2E1 and glutathione S-transferases M1, T1, and P1 on susceptibility to esophageal cancer among high-risk individuals in China. Cancer Epidemiol Biomarkers Prev 9: 551-556, 2000.

29. Wu X, Shi H, Jiang H, et al: Associations between cytochrome P4502E1 genotype, mutagen sensitivity, cigarette smoking and susceptibility to lung cancer. Carcinogenesis 18: 967-973, 1997.

30. London SJ, Daly AK, Cooper J, et al: Lung cancer risk in relation to the CYP2E1 Rsa I genetic polymorphism among African-Americans and Caucasians in Los Angeles County. Pharmacogenetics 6: 151-158, 1996.

31. Hildesheim A, Chen CJ, Caporaso NE, et al: Cytochrome P4502E1 genetic polymorphisms and risk of nasopharyngeal carcinoma: results from a case-control study conducted in Taiwan. Cancer Epidemiol Biomarkers Prev 4: 607-610, 1995.
32. Gonzalez FJ and Gelboin HV: Transcriptional and posttranscriptional regulation of CYP2E1, an N-nitrosodimethylamine demethylase. Princess Takamatsu Symp 21: 157-164, 1990.

33. Koop DR and Tierney DJ: Multiple mechanisms in the regulation of ethanol-inducible cytochrome P450IIE1. Bioessays 12: 429-435, 1990

34. Hakkola J, Hu Y and Ingelman-Sundberg M: Mechanisms of down-regulation of CYP2E1 expression by inflammatory cytokines in rat hepatoma cells. J Pharmacol Exp Ther 304: 1048-1054, 2003

35. Nakai K, Tanaka H, Hanada K, et al: Decreased expression of cytochromes P450 1A2, 2E1, and 3A4 and drug transporters $\mathrm{Na}^{+}$-taurocholate-cotransporting polypeptide, organic cation transporter 1 , and organic anion-transporting peptide-C correlates with the progression of liver fibrosis in chronic hepatitis C patients. Drug Metab Dispos 36: 1786-1793, 2008.

36. Morel Y, de Waziers I and Barouki R: A repressive crossregulation between catalytic and promoter activities of the CYP1A1 and CYP2E1 genes: role of $\mathrm{H}(2) \mathrm{O}(2)$. Mol Pharmacol 57: 1158-1164, 2000.

37. Bozina N, Bradamante V and Lovric M: Genetic polymorphism of metabolic enzymes P450 (CYP) as a susceptibility factor for drug response, toxicity, and cancer risk. Arh Hig Rada Toksikol 60: 217-242, 2009 . 